\title{
Improved Up-and-Down Procedure for Acute Toxicity Measurement With Reliable LD50 Verified by Typical Toxic Alkaloids and Modified Karber Method
}

\author{
Yan-Yu Zhang \\ Macau University of Science and Technology \\ Yu-Feng Huang \\ Macau University of Science and Technology \\ Jie Liang \\ Macau University of Science and Technology \\ Hua Zhou ( $\sim$ hzhou@must.edu.mo) \\ Macau University of Science and Technology
}

\section{Research Article}

Keywords: Acute toxicity, Improved up-and-down procedure, Median lethal dosage, Modified Karber method, Nicotine, Sinomenine hydrochloride, Berberine hydrochloride

Posted Date: January 13th, 2021

DOl: https://doi.org/10.21203/rs.3.rs-141073/v1

License: (c) (1) This work is licensed under a Creative Commons Attribution 4.0 International License. Read Full License

Version of Record: A version of this preprint was published at BMC Pharmacology and Toxicology on January 4th, 2022. See the published version at https://doi.org/10.1186/s40360-021-00541-7. 


\title{
Improved up-and-down procedure for acute toxicity
} measurement with reliable $L_{50}$ verified by typical toxic alkaloids and modified Karber method

\author{
Yan-Yu ZHANG ${ }^{1,2}$, Yu-Feng HUANG ${ }^{1,2}$, Jie LIANG ${ }^{1,2}$, Hua ZHOU ${ }^{1,2,3 *}$ \\ 1 Faculty of Chinese Medicine and State Key Laboratory of Quality Research in Chinese Medicine, \\ Macau University of Science and Technology, Taipa, Macao, P.R. China; \\ 2 Zhuhai Hospital of Integrated Traditional Chinese and Western Medicine, Zhuhai City, Guangdong \\ Province 519000, P.R. China; \\ 3 Joint Laboratory for Translational Cancer Research of Chinese Medicine of the Ministry of \\ Education of the People's Republic of China, Guangzhou University of Chinese Medicine, \\ Guangzhou 510006, P.R. China \\ * Correspondence to ZHOU Hua (hzhou@ must.edu.mo, Tel: +853-88972458, Fax : +853-28825886)
}

\section{Abstract}

Background: Up-and-down procedure (UDP) was recommended to replace traditional acute toxicity methods. However, it was limited due to the long experimental period (20 - 42 days). To improve UDP, an improved UDP method (iUDP) was developed by shortening observation time between sequence dosages. The aim of this study was to test the reliability of iUDP to provide a reliable method for the acute toxicity measurement of valuable or minor amount compounds.

Methods: Oral median lethal dosage $\left(\mathrm{LD}_{50}\right)$ of nicotine, sinomenine hydrochloride and berberine hydrochloride were measured both by iUDP and modified Karber method (mKM). Results: LD50 of the three alkaloids measured by iUDP with 23 mice were $32.71 \pm 7.46$, $453.54 \pm 104.59,2954.93 \pm 794.88 \mathrm{mg} / \mathrm{kg}$, respectively. LD50 of the three alkaloids measured by $\mathrm{mKM}$ with 240 mice were $22.99 \pm 3.01,456.56 \pm 53.38,2825.53 \pm 1212.92 \mathrm{mg} / \mathrm{kg}$, respectively. The average time consumed by the two methods were 22 days and 14 days respectively. Total grams of the alkaloids used by the two methods were 0.0082 and 0.0673 (nicotine), 0.114 and 1.24 (sinomenine hydrochloride), 1.9 and 12.7 (berberine hydrochloride).

Conclusion: iUDP could replace $\mathrm{mKM}$ to detect acute toxicity of substances with comparable and reliable result. And it was suitable for valuable or minor amount substances. 
Keywords: Acute toxicity; Improved up-and-down procedure; Median lethal dosage; Modified Karber method; Nicotine; Sinomenine hydrochloride; Berberine hydrochloride;

\section{Background}

Median lethal dosage (LD50) was first proposed by J. W. Trevan in 1976 [1]. It is used to study acute toxicity and classify toxic substance [2]. The 95\% confidence interval (95\% $\mathrm{CI}, \mu \pm \sigma)$ is used to describe $\mathrm{LD}_{50}$ mean $[3,4]$. Traditional acute toxicity methods to detect LD50 and 95\% CI include Bliss method [5, 6], mKM [7, 8], arithmetical method of Reed and Muench [9], and Miller and Tainter method [10]. For one substance, 50 80 mice would be administrated to obtain $\mathrm{LD}_{50}$ and $95 \% \mathrm{CI}$ in 14 days by traditional methods (a 14 day observation would carried on survival animals) $[11,12]$. However, traditional acute toxicity methods violate animal rights and increase economic pressure [2, 13-15]. With 3Rs principles proposed (Reduction, Replacement, Refinement) [16, 17], up-and-down procedure (UDP) was advocated $[14,18]$. In UDP, the dosage of $(\mathrm{N}+1)^{\text {th }}$ would be determined by the poisoning symptoms of $\mathrm{N}^{\text {th }}$ animal after administration. Observed the $\mathrm{N}^{\text {th }}$ animal for 48 hours, if it died, the dosage of $(\mathrm{N}+1)^{\text {th }}$ would be increased; Otherwise, dosage would be reduced. It is particularly time-consuming to test acute toxicity of one compound by UDP using 4 - 15 animals (Different toxicity compounds show different death and survival reversals, which may take 20 - 42 days, Table1). Analyzing 19160 journal articles on acute toxicity from January 1986 to October 2020 by SCI Finder, we found that UDP was used just in 144 articles to test acute toxicity of substances (Fig. 1). Low precision and long period limit the popularity of UDP in acute toxicity study [19-21]. Recently, several studies have gradually increased animal numbers to improve the reliability of UDP [22-25]. In addition, Hiller, D.B. and Yu Y used UDP to detect drug intravenous toxicity and they increased mice at each dosage to improve precision of results [26, 27]. Sarah C. Finch used UDP to test acute toxicity of tetrodotoxin and tetrodotoxin-saxitoxin mixtures under different routes (i.p. and p.o.) [28]. However, more animals mean more substances would be consumed which is not friendly to valuable or minor amount compounds. In this research, reducing observation time between sequence dosages rather than increasing animal number is applied to improve UDP. Nicotine, sinomenine hydrochloride and berberine hydrochloride, the three known toxic compounds 
are classic representatives of highly toxic, moderately toxic, and mildly toxic alkaloids. And they were poorly reported about oral acute toxicity of in mice $[29,30]$. This study aimed to evaluate the feasibility and reliability of iUDP by comparing the LD50 of the three alkaloids tested both by iUDP and mKM.

Table 1. Comparison between UDP and traditional acute toxicity test methods

\begin{tabular}{c|cccc}
\hline \multicolumn{1}{c}{ Method } & Mice & Time (day) & Precision \\
\hline & & & & 95\% CI was wide, \\
& UDP [31] & $4 \sim 15$ & $20 \sim 42$ & imprecise \\
\hline \multirow{2}{*}{$\begin{array}{c}\text { Traditional } \\
\text { acute toxicity }\end{array}$} & Bliss method [5] & $\sim 80$ & 14 & 95\% CI was narrow, precise \\
\cline { 2 - 4 } methods & mKM [32] & $\sim 80$ & 14 & $95 \%$ CI was narrow, precise \\
\hline
\end{tabular}

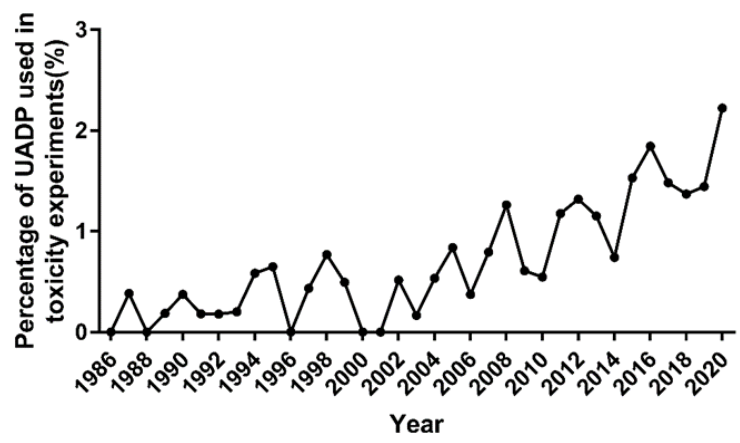

Fig.1. Percentage of UDP used in acute toxicity tests from January 1986 to October 2020

\section{Materials and Methods}

\section{Experimental animals}

A total of 263 ICR female mice ( $~ \sim 8$-week-old, $26 \sim 30 \mathrm{~g}$ ) were used. They were purchased from Beijing Vital River Laboratory Animal Technology Co., Ltd. The mice were housed in individually ventilated cages and had free access to food and water. A $12 \mathrm{~h}$ light/dark cycle was used in the room. The room temperature and humidity were $20 \sim 22^{\circ} \mathrm{C}$, $50 \sim 70 \%$, respectively. Before the start of the study, the animal experiments were approved by the Division of Animal Control and Inspection, Department of Food and Animal 
Inspection and Control, Instituto para os Assuntos Cívicos e Municipais (IACM), Macao (AL020/DICV/SIS/2018).

In the experiment, each mouse was weighed and fasted 4 hours with drink water freely before administration. For oral administration of nicotine and sinomenine hydrochloride, $0.2 \mathrm{ml}$ was given for every $10 \mathrm{~g}$ of mice body weight. And $0.4 \mathrm{ml}$ of berberine hydrochloride was given for every $10 \mathrm{~g}$ of mice body weight. After administration, the mice were fasted for 1 hour with drink water freely. When the experiment was stopped, all the survived mice were humanely killed and necropsied after a 14-day observation. Observed and recorded the pathological changes of viscera.

\section{Materials}

Nicotine (purity > 99\%, CAS: N3876-5ML) and berberine hydrochloride (purity > 99\%, CAS: B3251) were obtained from Sigma Chemical Company (St. Louis, MO, USA). Sinomenine hydrochloride (purity > 99\%, CAS: Y1509004) was kindly provided by Hunan Zhengqing Pharmaceutical Group Limited (Huaihua, Hunan Province, China).

\section{The acute toxicity assay of nicotine in mice by iUDP}

According to previous literature results, nicotine was a highly toxic substance. Therefore, the estimated initial LD50 dosage was $20 \mathrm{mg} / \mathrm{kg}$. Sigma was 0.2 , slope was 5 , and T was 1.6. Calculated the dosage by AOT425StatPgm. The sequential dosages were 2000, $1260,800,500,320,200,126,80,50,32,20,12.6,8,5,3.2,2 \mathrm{mg} / \mathrm{kg}$. The first dosage of $12.6 \mathrm{mg} / \mathrm{kg}$ was given to the first mouse. Symptoms of poisoning were recorded within 24 hours. If it was survived, $20 \mathrm{mg} / \mathrm{kg}$ was given as the second dosage. If it died, $8 \mathrm{mg} / \mathrm{kg}$ was chosen. Follow the experimental sequence until the standard stopping rules appeared.

\section{The acute toxicity assay of sinomenine hydrochloride in mice by iUDP}

According to previous literature results, sinomenine hydrochloride was moderately toxic with a significant dosage-response relationship [30, 33]. Therefore, the estimated initial LD 50 dosage was $175 \mathrm{mg} / \mathrm{kg}$. Sigma was 0.2 , slope was 5 , and T was 1.6. Calculated the dosage by AOT425StatPgm. The sequential dosages were 2000, 1100, 700, 440, 280, 175, $110,70,44,28,17.5,11,7,4.4,2.8,1.75 \mathrm{mg} / \mathrm{kg}$. The first dosage of $175 \mathrm{mg} / \mathrm{kg}$ was given to the first mouse. Symptoms of poisoning were recorded within 24 hours. If it was survived, $280 \mathrm{mg} / \mathrm{kg}$ was given as the second dosage. If it died, $110 \mathrm{mg} / \mathrm{kg}$ was chosen. Follow the experimental sequence until the standard stopping rules appeared. 


\section{The acute toxicity assay ofberberine hydrochloride in mice by iUDP}

According to previous literature results, berberine hydrochloride was a low or non-toxic compound. Therefore, the estimated initial LD50 dosage was $2500 \mathrm{mg} / \mathrm{kg}$. Sigma was 0.5 , slope was 2, and $\mathrm{T}$ was 3.16. Calculated the dosage by AOT425StatPgm. The sequential dosages were $5000,2500,790,250,79,25,7.9,2.5,0.79 \mathrm{mg} / \mathrm{kg}$. The first dosage of 790 $\mathrm{mg} / \mathrm{kg}$ was given to the first mouse. Symptoms of poisoning were recorded within 24 hours. If it was survived, $2500 \mathrm{mg} / \mathrm{kg}$ was given as the second dosage. If it died, $250 \mathrm{mg} / \mathrm{kg}$ was chosen. Follow the experimental sequence until the standard stopping rules appeared.

\section{The acute toxicity assay of nicotine in mice by $\mathrm{mKM}$}

Twenty-four ICR female mice were randomly divided into 4 groups. The dosage ratio was 0.7 , and oral dosage was $14,20,28.5,40.8 \mathrm{mg} / \mathrm{kg}$. The lowest dosage with $100 \%$ mortality $(\mathrm{Dm}=40.8 \mathrm{mg} / \mathrm{kg})$ and the highest dosage with $0 \%$ mortality $(14 \mathrm{mg} / \mathrm{kg})$ were obtained to provide references for subsequent experiments.

Fifty ICR female mice were randomly divided into 5 groups. The lowest and highest dosage were selected $(16 \mathrm{mg} / \mathrm{kg}, 39.1 \mathrm{mg} / \mathrm{kg}$, respectively). And 0.8 was chosen as the dosage ratio. After dosing, symptoms of poisoning, number of survival and dead mice were recorded. All mice were subjected to gross necropsy

\section{The acute toxicity assay of sinomenine hydrochloride in mice by mKM}

Twenty-four ICR female mice were randomly divided into 4 groups. The dosage ratio was 0.7 , and oral dosage was $350,500,665,715 \mathrm{mg} / \mathrm{kg}$. Obtained the lowest dosage of $100 \%$ mortality $(\mathrm{Dm}=665 \mathrm{mg} / \mathrm{kg})$ and the highest dosage of $16 \%$ mortality $(350 \mathrm{mg} / \mathrm{kg})$. To obtain the highest dosage with $0 \%$ mortality (Dn), $300 \mathrm{mg} / \mathrm{kg}$ was added.

Fifty ICR female mice were randomly into 5 groups. The lowest and highest dosage were selected (300 mg/kg, $665 \mathrm{mg} / \mathrm{kg}$, respectively). And 0.82 was chosen as the dosage ratio. After dosing, symptoms of poisoning, number of survival and dead mice were recorded. All mice were subjected to gross necropsy.

\section{The acute toxicity assay of berberine hydrochloride in mice by mKM}

Twenty-four ICR female mice were randomly divided into 4 groups. The dosage ratio was 0.5 , and oral dosage was $1000,2000,4000,8000 \mathrm{mg} / \mathrm{kg}$. The lowest dosage with $90 \%$ mortality $(8000 \mathrm{mg} / \mathrm{kg})$ and the highest dosage with $16.7 \%$ mortality $(1000 \mathrm{mg} / \mathrm{kg})$ were obtained. Then 11428 (100\% mortality) and $700 \mathrm{mg} / \mathrm{kg}$ (0\% mortality) were carried out. 
Fifty ICR female mice were randomly into 5 groups. The lowest and highest dosage were selected $(703 \mathrm{mg} / \mathrm{kg}, 11250 \mathrm{mg} / \mathrm{kg}$, respectively). And 0.5 was chosen as the dosage ratio. After dosing, symptoms of poisoning, number of survival and dead mice were recorded. All mice were subjected to gross necropsy.

\section{Statistical Analyses}

In iUDP, the dosage and numbers of all survival and dead mice were recorded. The computational formula as follows:

$$
\begin{gathered}
\mathrm{LD}_{50}=\sum(\mathrm{Xi}) / \mathrm{N}+(\mathrm{A}+\mathrm{C}) * \mathrm{~d} / \mathrm{N}, \\
\mathrm{SE}=\mathrm{SD} * \sqrt{ }(2 / \mathrm{N}),
\end{gathered}
$$

$\mathrm{Xi}$ was the dosage level, $\mathrm{N}$ was the total number of animals, $\mathrm{A}$ and $\mathrm{C}$ values were obtained from Dixon's tables [30], which were obtained from the number of $\mathrm{O}$ and $\mathrm{X}$ in $\mathrm{N}$ trials. And d was $\lg D$ minus $\lg \mathrm{D}(\mathrm{n}+1)$, SE was the standard error, SD was the standard deviation of all dosages in $\mathrm{N}$ trails.

In mKM, mortality rate of each group was calculated, and then values were substituted into formulas to obtain $\mathrm{LD}_{50}$ [34]. The computational formula as follows:

$$
\begin{aligned}
& \operatorname{LgLD}_{50}=\operatorname{LgDmax}-(\operatorname{LgDN}-\operatorname{LgD}(\mathrm{N}+1))\left(\sum \mathrm{p}-0.5\right), \\
& \mathrm{SE}_{50}=\mathrm{I}^{*} \sqrt{ }\left(\left(\sum \mathrm{p}-\sum \mathrm{p}^{\wedge} 2\right) /(\mathrm{n}-1)\right), \\
& \mathrm{d}= \pm 4.5 * \mathrm{LD}_{50} * \mathrm{SE}_{50} \\
& \text { CI of } 95 \%=\mathrm{LD}_{50} \pm \mathrm{d} \text {, }
\end{aligned}
$$

$\mathrm{m}$ was $\mathrm{LgLD}_{50}$, D was the dosage of each group, Dmax was maximum dosage level, DN was the dosage of $\mathrm{N}$ group, $\mathrm{D}(\mathrm{N}+1)$ was the dosage of $(\mathrm{N}+1)$ group, $\mathrm{p}$ was the mortality of each group of animals, and d was the standard error $(\sigma), \operatorname{I}$ was $\operatorname{LgDN}$ minus $\operatorname{LgD}(\mathrm{N}+1)$, and $\mathrm{n}$ was the number of animals in each group.

Data of organ indexes were plotted in GraphPad Prism (7.0) using One-way ANOVA. And data were presented in mean $\pm \mathrm{SD}, * \mathrm{P}<0.05$ vs Normal, $* * \mathrm{P}<0.01$ vs Normal.

\section{Results}


The result was calculated as follows according to the results of Table 2 and formula (1), (2).

$$
\begin{gathered}
\mathrm{LD}_{50}=228.6 / 7+(1.53+0.17) * 0.2 / 7=32.71 \\
\mathrm{SE}=13.96 * \sqrt{ } 2 / 7=7.46
\end{gathered}
$$

Therefore, the $\mathrm{LD}_{50}$ for nicotine was $32.71 \mathrm{mg} / \mathrm{kg}$ and the $95 \%$ CI was $[25.25,40.17]$.

Compared to normal mice, lung in mice administrated with different dosage of nicotine was enlarged (Table 3). There was a good dosage-effect relationship of nicotine on lung injury in mice. As seen in Table 3, 20 and $32 \mathrm{mg} / \mathrm{kg}$ of nicotine increased lung weight in mice ( $\mathrm{P}<0.01, \mathrm{P}<0.01$, respectively). $50 \mathrm{mg} / \mathrm{kg}$ of nicotine significantly increased heart and lung weight in mice $(\mathrm{P}<0.01, \mathrm{P}<0.01)$. The organs of mice were shown in Fig. 2.

\begin{tabular}{|c|c|c|c|c|c|}
\hline Seq. & $\begin{array}{c}\text { Dose } \\
\text { (mg/kg) }\end{array}$ & $\Delta \mathbf{m}(\mathrm{g})$ & $\begin{array}{l}\text { Short-term } \\
\text { outcome }\end{array}$ & Symptoms & Pathology \\
\hline 1 & 12.6 & 1.1 & $\mathrm{O}$ & $\begin{array}{l}\text { Convulsive, weakness, } \\
\text { recovered after } 2 \mathrm{~h}\end{array}$ & $\begin{array}{c}\text { No visible lesions } \\
\text { were found in organs } \\
\text { and tissues }\end{array}$ \\
\hline 2 & 20 & 1.5 & $\mathrm{O}$ & $\begin{array}{l}\text { Violently convulsive, } \\
\text { recovered after } 2 \mathrm{~h}\end{array}$ & $\begin{array}{l}\text { Spleen was enlarged } \\
\text { and in deep red color }\end{array}$ \\
\hline 3 & 32 & 1.4 & $\mathrm{O}$ & $\begin{array}{c}\text { Violently convulsive, } \\
\text { weakness, recovered after } \\
6 \mathrm{~h}\end{array}$ & $\begin{array}{l}\text { Lung was enlarged } \\
\text { and in deep red color }\end{array}$ \\
\hline 4 & 50 & 0.9 & $X$ & $\begin{array}{l}\text { Violently convulsive, dead } \\
\text { after } 5 \mathrm{~min}\end{array}$ & $\begin{array}{c}\text { Heart and lung were } \\
\text { enlarged }\end{array}$ \\
\hline 5 & 32 & 1.1 & $\mathrm{O}$ & $\begin{array}{c}\text { Violently convulsive, } \\
\text { weakness, recovered after } \\
6 \mathrm{~h}\end{array}$ & $\begin{array}{l}\text { Heart and lung were } \\
\text { markedly enlarged }\end{array}$ \\
\hline 6 & 50 & 1.7 & $X$ & $\begin{array}{l}\text { Violently convulsive, dead } \\
\text { after } 10 \mathrm{~min}\end{array}$ & $\begin{array}{c}\text { Heart, liver and lung } \\
\text { were enlarged }\end{array}$ \\
\hline 7 & 32 & 1.4 & $X$ & $\begin{array}{l}\text { Violently convulsive, dead } \\
\text { after } 5 \mathrm{~min}\end{array}$ & $\begin{array}{c}\text { Heart, liver and lung } \\
\text { were enlarged }\end{array}$ \\
\hline
\end{tabular}

Table 2. Lethality and signs of toxicity of nicotine in mice tested by iUDP 
Stop criteria met: 3 reversals in 5 tests

Note: The sequence of outcomes: $\mathrm{O}$ for alive and $\mathrm{X}$ for dead.

Table 3. Effect of nicotine on organ indexes in ICR mice by iUDP

\begin{tabular}{cccccc}
\hline $\begin{array}{c}\text { Dose } \\
(\mathbf{m g} / \mathbf{k g})\end{array}$ & Heart $(\%)$ & Liver $(\%)$ & Spleen $(\%)$ & Lung (\%) & Kidney (\%) \\
\hline 0 & $0.466 \pm 0.002$ & $4.800 \pm 0.373$ & $0.387 \pm 0.079$ & $0.588 \pm 0.057$ & $1.282 \pm 0.140$ \\
12.6 & 0.491 & 4.665 & 0.370 & 0.609 & 1.248 \\
20 & 0.485 & 4.250 & 0.381 & $0.643 * *$ & 1.185 \\
32 & $0.474 \pm 0.018$ & $4.548 \pm 0.505$ & $0.366 \pm 0.084$ & $0.653 \pm 0.056^{* *}$ & $1.170 \pm 0.058$ \\
50 & $0.581 \pm 0.051^{* *}$ & $5.123 \pm 0.155$ & $0.385 \pm 0.063$ & $0.702 \pm 0.015^{* *}$ & $1.107 \pm 0.007$ \\
\hline
\end{tabular}

Note: $* \mathrm{P}<0.05$ vs Normal, $* * \mathrm{P}<0.01$ vs Normal.

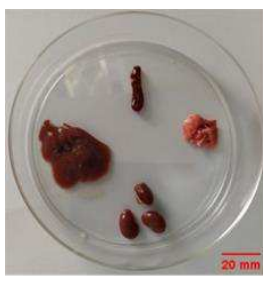

a

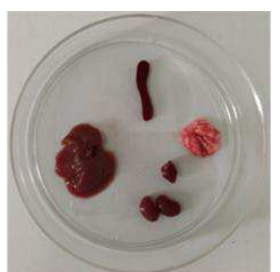

b

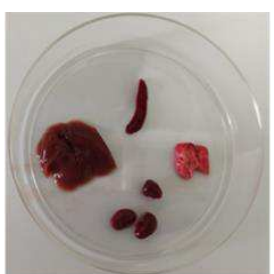

C

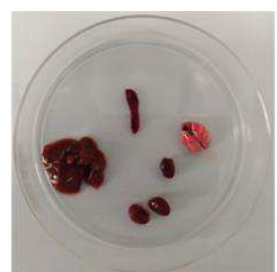

d

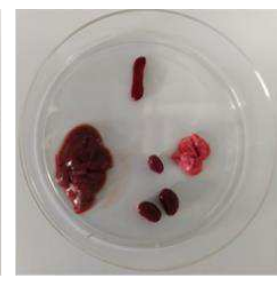

$\mathrm{e}$
173

Fig. 2. Organs of mice administrated different dosage of nicotine by iUDP. (a) Control; (b) $12.6 \mathrm{mg} / \mathrm{kg}$; (c) $20 \mathrm{mg} / \mathrm{kg}$; (d) $32 \mathrm{mg} / \mathrm{kg}$; (e) $50 \mathrm{mg} / \mathrm{kg}$.

\section{The $\mathrm{LD}_{50}$ and toxicity of sinomenine hydrochloride in mice detected by iUDP}

The result was calculated as follows according to the results of Table 4 and formula (1), (2).

$$
\begin{array}{r}
\mathrm{LD}_{50}=3175 / 7+(1.53+0.16) * 0.2 / 7=453.54, \\
\mathrm{SE}=195.67 * \sqrt{ } 2 / 7=104.59,
\end{array}
$$

Therefore, the $\mathrm{LD}_{50}$ of sinomenine hydrochloride was $453.54 \mathrm{mg} / \mathrm{kg}$ and the $95 \% \mathrm{CI}$ was [349.0, 558.2].

Compared to normal mice, sinomenine hydrochloride has no effect on the organ indexes (Table 5). No visible lesions were found in organs and tissues in mice administrated with low dosage of sinomenine hydrochloride (Fig. 3).

Table 4. Lethality and signs of toxicity of mice after administration of sinomenine 
hydrochloride by iUDP

\begin{tabular}{|c|c|c|c|c|c|}
\hline Seq. & $\begin{array}{l}\text { Dosage } \\
(\mathrm{mg} / \mathrm{kg})\end{array}$ & $\begin{array}{l}\Delta \mathbf{m} \\
(\mathrm{g})\end{array}$ & $\begin{array}{l}\text { Short-term } \\
\text { outcome }\end{array}$ & Symptoms & Pathology \\
\hline 1 & 175 & 1.1 & $\mathrm{O}$ & $\begin{array}{l}\text { Mild, shortness of breath, } \\
\text { frightened, recovered after } 2 \mathrm{~h}\end{array}$ & $\begin{array}{l}\text { No visible lesions were } \\
\text { found in organs }\end{array}$ \\
\hline 2 & 280 & 1.4 & $\mathrm{O}$ & $\begin{array}{c}\text { Shortness of breath, frightened, } \\
\text { recovered after } 5 \mathrm{~h}\end{array}$ & $\begin{array}{l}\text { No visible lesions were } \\
\text { found in organs }\end{array}$ \\
\hline 3 & 440 & 1.8 & $\mathrm{O}$ & $\begin{array}{l}\text { Tremor, breathlessness, and } \\
\text { recovered after } 2 \mathrm{~h}\end{array}$ & Liver were enlarged \\
\hline 4 & 700 & 1.3 & $\mathrm{X}$ & $\begin{array}{c}\text { Severe tremor, weakness, dead } \\
\text { after 30min }\end{array}$ & Liver was enlarged \\
\hline 5 & 440 & 1.5 & $\mathrm{O}$ & $\begin{array}{l}\text { Mild tremor, weakness, and } \\
\text { recovered after } 2 \mathrm{~h}\end{array}$ & $\begin{array}{c}\text { Liver and kidney were } \\
\text { enlarged }\end{array}$ \\
\hline 6 & 700 & 0.9 & $\mathrm{X}$ & $\begin{array}{c}\text { Severe tremor, weakness, dead } \\
\text { after } 1 \mathrm{~h}\end{array}$ & Liver was enlarged \\
\hline 7 & 440 & 0.9 & $\mathrm{X}$ & $\begin{array}{l}\text { Breathlessness, tremor, and } \\
\text { dead after } 4 \mathrm{~h}\end{array}$ & $\begin{array}{c}\text { Liver and kidney were } \\
\text { enlarged }\end{array}$ \\
\hline \multicolumn{6}{|c|}{ Stop criteria met: 5 reversals in 6 tests } \\
\hline
\end{tabular}

Note: The sequence of outcomes: $\mathrm{O}$ for alive and $\mathrm{X}$ for dead.

Table 5. Effect of sinomenine hydrochloride on organ indexes in ICR mice by iUDP

\begin{tabular}{cccccc}
\hline Dosage $(\mathbf{m g} / \mathbf{k g})$ & Heart (\%) & Liver (\%) & Spleen (\%) & Lung (\%) & Kidney (\%) \\
\hline 0 & $0.466 \pm 0.002$ & $4.800 \pm 0.373$ & $0.387 \pm 0.079$ & $0.588 \pm 0.057$ & $1.282 \pm 0.140$ \\
175 & 0.550 & 4.660 & 0.312 & 0.623 & 1.120 \\
280 & 0.450 & 4.258 & 0.467 & 0.578 & 1.295 \\
440 & $0.403 \pm 0.012$ & $4.382 \pm 0.442$ & $0.345 \pm 0.082$ & $0.519 \pm 0.110$ & $1.110 \pm 0.035^{*}$ \\
700 & $0.315 \pm 0.065^{* *}$ & $4.452 \pm 0.486$ & $0.293 \pm 0.033^{* *}$ & $0.566 \pm 0.065$ & $1.005 \pm 0.085^{* *}$ \\
\hline
\end{tabular}

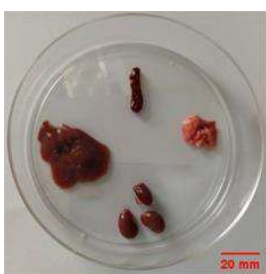

a

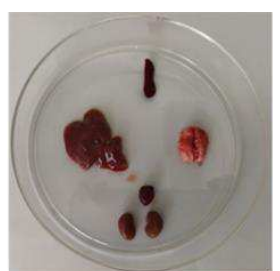

b

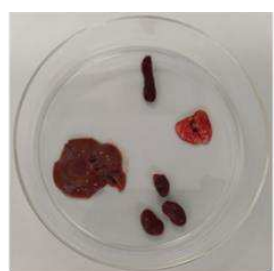

C

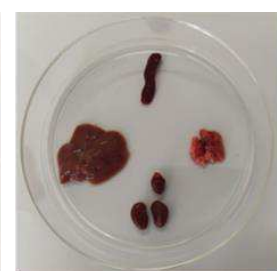

d

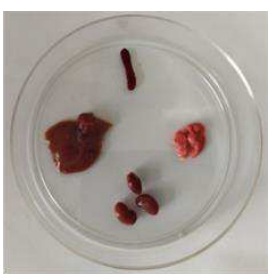

$\mathrm{e}$ 
Fig. 3. Organs of mice administrated different dosage of sinomenine hydrochloride by iUDP. (a) Control; (b) $175 \mathrm{mg} / \mathrm{kg}$; (c) $280 \mathrm{mg} / \mathrm{kg}$; (d) $440 \mathrm{mg} / \mathrm{kg}$; (e) $700 \mathrm{mg} / \mathrm{kg}$.

\section{The $\mathrm{LD}_{50}$ and toxicity of berberine hydrochloride in mice detected by iUDP}

The result was calculated as follows according to the results of Table 6 and formula (1), (2).

$$
\begin{gathered}
\mathrm{LD}_{50}=26580 / 9+(1.53+0.16) * 0.2 / 9=2954.93, \\
\mathrm{SE}=1686.29 * \sqrt{ }(2 / 9)=794.88,
\end{gathered}
$$

Therefore, the $\mathrm{LD}_{50}$ of berberine hydrochloride was $2954.93 \mathrm{mg} / \mathrm{kg}$ and the $95 \% \mathrm{CI}$ was [2160.05, 3749.81].

Compared to normal mice, $5000 \mathrm{mg} / \mathrm{kg}$ of berberine hydrochloride increased spleen weight in mice $(P<0.05$, Table 7). No visible lesions were found in organs and tissues in mice administrated with berberine hydrochloride (Fig. 4).

Table 6. Lethality and signs of toxicity of mice after administration of berberine

\begin{tabular}{|c|c|c|c|c|c|}
\hline Seq. & $\begin{array}{l}\text { Dosage } \\
(\mathrm{mg} / \mathrm{kg})\end{array}$ & $\Delta \mathrm{m}(\mathrm{g})$ & $\begin{array}{c}\text { Short-term } \\
\text { outcome }\end{array}$ & Symptoms & Pathology \\
\hline 1 & 790 & 1.1 & $\mathrm{O}$ & $\begin{array}{l}\text { Reduced activity, } \\
\text { recovered after } 2 \mathrm{~h}\end{array}$ & $\begin{array}{c}\text { No visible lesions were } \\
\text { found in organs and } \\
\text { tissues }\end{array}$ \\
\hline 2 & 2500 & 1.5 & $\mathrm{O}$ & $\begin{array}{l}\text { Reduced activity, } \\
\text { recovered after } 4.5 \mathrm{~h}\end{array}$ & $\begin{array}{c}\text { No visible lesions were } \\
\text { found in organs and } \\
\text { tissues }\end{array}$ \\
\hline 3 & 5000 & 1.4 & $\mathrm{X}$ & $\begin{array}{c}\text { Reduced activity, } \\
\text { weakness, dead after } \\
10 \mathrm{~h}\end{array}$ & $\begin{array}{c}\text { Liver was in deep red } \\
\text { color }\end{array}$ \\
\hline 4 & 2500 & 0.9 & $\mathrm{O}$ & $\begin{array}{l}\text { Reduced activity, } \\
\text { recovered after } 4.5 \mathrm{~h}\end{array}$ & $\begin{array}{c}\text { No visible lesions were } \\
\text { found in organs and } \\
\text { tissues }\end{array}$ \\
\hline
\end{tabular}
hydrochloride by iUDP 


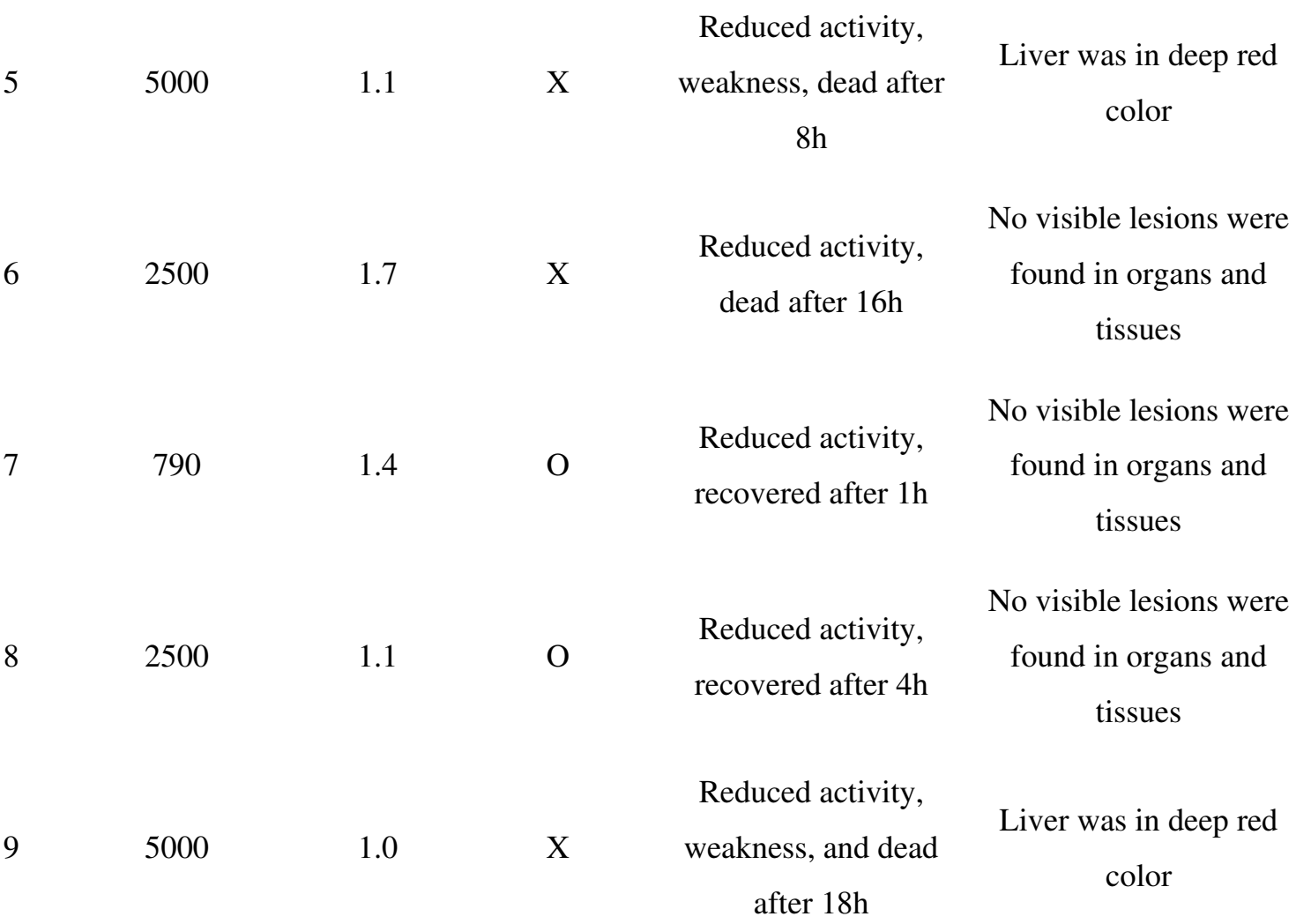

Stop criteria met: 3 reversals in 5 tests

Note: The sequence of outcomes: $\mathrm{O}$ for alive and $\mathrm{X}$ for dead.

Table 7. Effect of berberine hydrochloride on organ indexes in ICR mice by iUDP

\begin{tabular}{cccccc}
\hline Dosage $(\mathbf{m g} / \mathbf{k g})$ & Heart $(\%)$ & Liver $(\%)$ & Spleen $(\%)$ & Lung (\%) & Kidney (\%) \\
\hline 0 & $0.466 \pm 0.002$ & $4.800 \pm 0.373$ & $0.387 \pm 0.079$ & $0.588 \pm 0.057$ & $1.282 \pm 0.140$ \\
790 & $0.472 \pm 0.028$ & $4.602 \pm 0.295$ & $0.363 \pm 0.063$ & $0.580 \pm 0.097$ & $1.100 \pm 0.100$ \\
2500 & $0.449 \pm 0.045$ & $4.472 \pm 0.207$ & $0.427 \pm 0.096$ & $0.627 \pm 0.108$ & $1.280 \pm 0.073$ \\
5000 & $0.465 \pm 0.039$ & $4.503 \pm 0.200$ & $0.426 \pm 0.041 *$ & $0.598 \pm 0.049$ & $1.129 \pm 0.068$ \\
\hline Note: $* \mathrm{P}<0.05$ vs Normal, **P < 0.01 vs Normal.
\end{tabular}

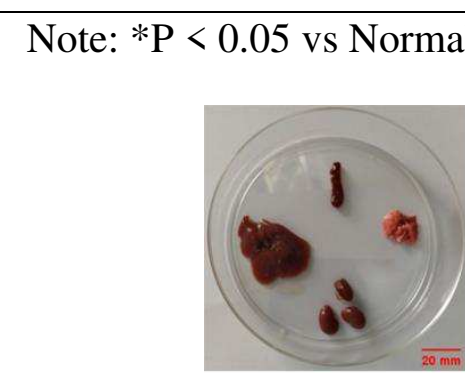

a

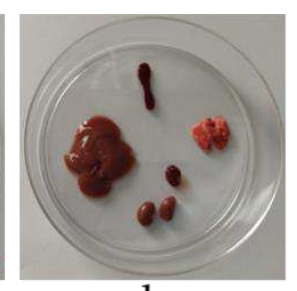

b

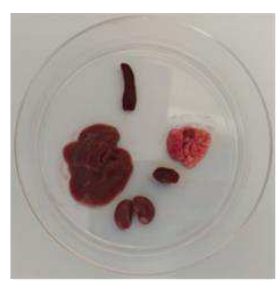

C

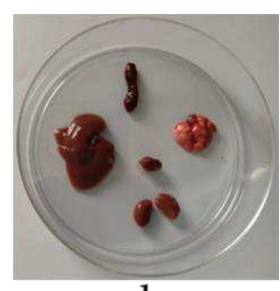

d

Fig. 4. Organs of mice administrated different dosage of berberine hydrochloride by iUDP. (a) Control; (b) $790 \mathrm{mg} / \mathrm{kg}$; (c) $2500 \mathrm{mg} / \mathrm{kg}$; (d) $5000 \mathrm{mg} / \mathrm{kg}$. 
Table 8. Lethality and signs of toxicity of mice after administration of nicotine by mKM

\begin{tabular}{|c|c|c|c|c|c|}
\hline Group & $\mathbf{n}$ & $\begin{array}{c}\text { Dosage }(\mathrm{mg} / \mathrm{kg} \\
)\end{array}$ & $\begin{array}{c}\text { Morality（p } \\
\text { ) }\end{array}$ & p2 & Pathology \\
\hline 1 & 10 & 16 & 0.2 & 0.04 & $\begin{array}{l}\text { No visible lesions were found in } \\
\text { other organs and tissues. }\end{array}$ \\
\hline 2 & 10 & 20 & 0.3 & 0.09 & $\begin{array}{l}\text { Liver was enlarged and in deep } \\
\text { red color }\end{array}$ \\
\hline 3 & 10 & 25 & 0.7 & 0.49 & $\begin{array}{l}\text { Liver was enlarged and in deep } \\
\text { red color }\end{array}$ \\
\hline 4 & 10 & 31.25 & 0.8 & 0.64 & $\begin{array}{c}\text { Liver and kidney were enlarged } \\
\text { and in deep red color }\end{array}$ \\
\hline 5 & 10 & 39.1 & 0.9 & 0.81 & $\begin{array}{c}\text { Liver and kidney were } \\
\text { significantly enlarged and in } \\
\text { deep red color }\end{array}$ \\
\hline
\end{tabular}

\section{The $\mathrm{LD}_{50}$ and toxicity of nicotine in mice detected by $\mathrm{mKM}$}

The result was calculated as follows according to Table 8 and formula $(3,4,5,6)$.

$$
\begin{gathered}
\operatorname{LgLD}_{50}=\lg 39.1-(\lg 20-\lg 16) *[2.9-0.5]=1.3616 \\
\operatorname{LD}_{50}=22.99 \\
\mathrm{SE}_{50}=0.096 * \sqrt{ }((2.9-2.07) /(10-1))=0.02915 \\
\mathrm{SE}= \pm 4.5 * 22.99 * 0.02915=3.02
\end{gathered}
$$

Therefore, the LD50 of nicotine was $22.99 \mathrm{mg} / \mathrm{kg}$ and the $95 \%$ CI was [19.97, 26.01].

Compared to normal mice, 20 and $32 \mathrm{mg} / \mathrm{kg}$ of nicotine increased lung weight in mice ( $\mathrm{P}<0.05, \mathrm{P}<0.01$, respectively). $50 \mathrm{mg} / \mathrm{kg}$ of nicotine significantly increased heart and lung weight in mice $(\mathrm{P}<0.01, \mathrm{P}<0.01$, Table 9). As seen in Fig 5, lung in mice administrated with different dosage of nicotine were enlarged.

Note: The sequence of outcomes: O for alive and $\mathrm{X}$ for dead.

Table 9. Effect of different doses of nicotine on organ indexes in ICR mice by mKM

$\begin{array}{llllll}\text { Dosage }(\mathrm{mg} / \mathrm{kg}) & \text { Hear }(\%) & \text { Liver (\%) } & \text { Spleen (\%) } & \text { Lung (\%) } & \text { Kidney (\%) }\end{array}$




\begin{tabular}{cccccc}
\hline 0 & $0.466 \pm 0.002$ & $4.800 \pm 0.373$ & $0.387 \pm 0.079$ & $0.588 \pm 0.057$ & $1.282 \pm 0.140$ \\
16 & $0.467 \pm 0.023$ & $4.667 \pm 0.317$ & $0.412 \pm 0.066$ & $0.603 \pm 0.046$ & $1.177 \pm 0.075$ \\
20 & $0.482 \pm 0.061$ & $4.772 \pm 0.476$ & $0.468 \pm 0.068$ & $0.603 \pm 0.081$ & $1.220 \pm 0.064$ \\
25 & $0.431 \pm 0.002$ & $4.825 \pm 0.034$ & $0.578 \pm 0.154$ & $0.665 \pm 0.038^{*}$ & $1.211 \pm 0.021$ \\
31.25 & $0.437 \pm 0.009$ & $4.272 \pm 0.363$ & $0.423 \pm 0.022$ & $0.692 \pm 0.058^{* *}$ & $1.187 \pm 0.052$ \\
39.10 & $0.490 \pm 0.041$ & $4.891 \pm 0.105$ & $0.391 \pm 0.055$ & $0.700 \pm 0.020^{* *}$ & $1.137 \pm 0.09$
\end{tabular}

Note: $* \mathrm{P}<0.05$ vs Normal, $* * \mathrm{P}<0.01$ vs Normal.

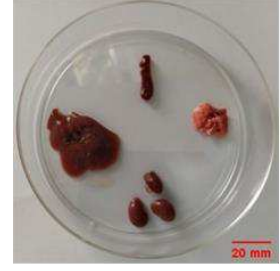

a

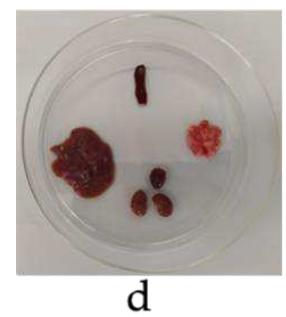

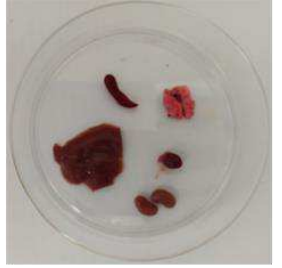

b

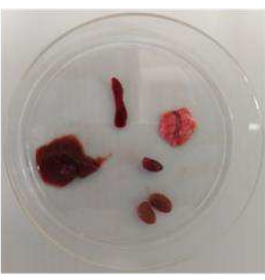

$\mathrm{e}$

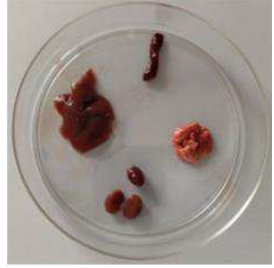

C

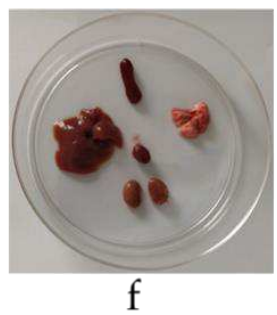

Fig. 5. Organs of mice administrated different dosage of nicotine by mKM. (a) Control; (b) $16 \mathrm{mg} / \mathrm{kg}$; (c) $20 \mathrm{mg} / \mathrm{kg}$; (d) $25 \mathrm{mg} / \mathrm{kg}$; (e) $31.25 \mathrm{mg} / \mathrm{kg}$; (f) $39.1 \mathrm{mg} / \mathrm{kg}$.

The $\mathrm{LD}_{50}$ and toxicity of sinomenine hydrochloride in mice detected by $\mathrm{mKM}$

The result was calculated as follows according to Table $\mathbf{1 0}$ and formula $(3,4,5,6)$.

$$
\begin{gathered}
\operatorname{LgLD}_{50}=\lg 663-(\lg 300-\lg 365) *[2.3-0.5]=2.66, \\
\operatorname{LD}_{50}=456.56, \\
\mathrm{SE}_{50}=0.09 * \sqrt{ }((2.3-1.55) /(10-1))=0.02598, \\
\mathrm{SE}= \pm 4.5 * 456.56 * 0.02598=53.38,
\end{gathered}
$$

Therefore, the $\mathrm{LD}_{50}$ of sinomenine hydrochloride was $456.56 \mathrm{mg} / \mathrm{kg}$ and he $95 \%$ CI was [403.18, 509.94].

Compared to normal mice, the heart and kidney in mice administrated by $665 \mathrm{mg} / \mathrm{kg}$ of sinomenine hydrochloride were enlarged $(\mathrm{P}<0.05, \mathrm{P}<0.01$, respectively, Table 11). As seen in Fig. 6, no visible lesions were found in organs and tissues in mice administrated with sinomenine hydrochloride. 
10

300

365

446

544

663

\section{Morality}

(p) p2

Pathology
No visible lesions were found in other

0

organs and tissues

Liver was enlarged and in deep red 0.09

color

Liver was enlarged and in deep red

$0.4 \quad 0.16$

color

Liver and kidney were enlarged and in

deep red color

Liver and kidney were significantly enlarged and in deep red color

Table 11. Effect of different doses of sinomenine hydrochloride on organ indexes in ICR mice by $\mathrm{mKM}$

\begin{tabular}{cccccc}
\hline Dosage(mg/kg) & Hear $(\%)$ & Liver $(\%)$ & Spleen $(\%)$ & Lung $(\%)$ & Kidney $(\%)$ \\
\hline 0 & $0.466 \pm 0.002$ & $4.800 \pm 0.373$ & $0.387 \pm 0.079$ & $0.588 \pm 0.057$ & $1.282 \pm 0.140$ \\
300 & $0.494 \pm 0.091$ & $4.948 \pm 0.500$ & $0.404 \pm 0.085$ & $0.571 \pm 0.109$ & $1.217 \pm 0.184$ \\
365 & $0.454 \pm 0.036$ & $4.925 \pm 0.298$ & $0.393 \pm 0.063$ & $0.586 \pm 0.092$ & $1.101 \pm 0.104$ \\
446 & $0.403 \pm 0.012$ & $4.382 \pm 0.442$ & $0.335 \pm 0.082$ & $0.519 \pm 0.110$ & $1.210 \pm 0.035$ \\
544 & $0.421 \pm 0.037$ & $3.931 \pm 0.240$ & $0.327 \pm 0.078$ & $0.543 \pm 0.022$ & $1.109 \pm 0.110 *$ \\
663 & $0.345 \pm 0.035 * *$ & $4.327 \pm 0.248$ & $0.305 \pm 0.021$ & $0.554 \pm 0.054$ & $0.973 \pm 0.063 * *$ \\
\hline
\end{tabular}




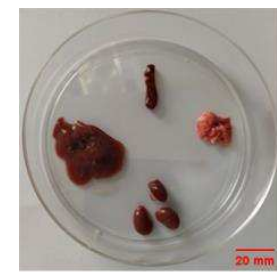

a

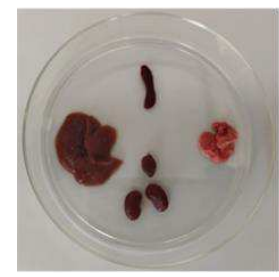

d

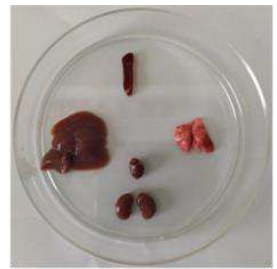

b

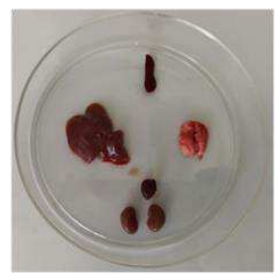

e

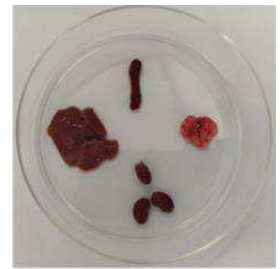

C

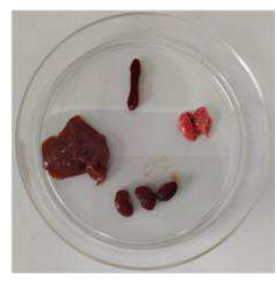

$\mathrm{f}$
235

236

237

238

239

240

241

242

243

244

245

246

247

Fig. 6. Organs of mice administrated different dosage of sinomenine hydrochloride by mKM. (a) Control; (b) $300 \mathrm{mg} / \mathrm{kg}$; (c) $365 \mathrm{mg} / \mathrm{kg}$; (d) $446 \mathrm{mg} / \mathrm{kg}$; (e) $544 \mathrm{mg} / \mathrm{kg}$; (f) $663 \mathrm{mg} / \mathrm{kg}$.

The $\mathrm{LD}_{50}$ and toxicity of berberine hydrochloride in mice detected by $\mathrm{mKM}$

The result was calculated as follows according to Table 12 and formula $(3,4,5,6)$.

$$
\begin{gathered}
\operatorname{LgLD}_{50}=\lg 11250-(\lg 1406-\lg 703) *[2.5-0.5]=3.4511, \\
\operatorname{LD}_{50}=2825.53 \\
\mathrm{SE}_{50}=0.3 * \sqrt{ }((2.5-1.59) /(10-1))=0.09539 \\
\mathrm{SE}= \pm 4.5 * 2825.53 * 0.09539=1212.92
\end{gathered}
$$

Therefore, the LD50 of berberine hydrochloride was $2825.53 \mathrm{mg} / \mathrm{kg}$ and the $95 \% \mathrm{CI}$ was [1612.60, 4038.45].

Compared to normal mice, the liver, spleen and lung in mice administrated by 11250 $\mathrm{mg} / \mathrm{kg}$ of berberine hydrochloride were enlarged $(\mathrm{P}<0.01, \mathrm{P}<0.01, \mathrm{P}<0.01$, Table 13). As seen in Fig. 7, the liver, spleen and lung in mice administrated with high dosages of sinomenine hydrochloride were enlarged.

Table 12. Lethality and signs of toxicity of mice after administration of berberine hydrochloride by $\mathrm{mKM}$

\begin{tabular}{lccccc}
\hline Group & n & Dosage $(\mathrm{mg} / \mathrm{kg}$ & Morality $(\mathrm{p})$ & p2 & Pathology \\
& & & & & \\
\hline
\end{tabular}




\begin{tabular}{cccccc}
\hline 1 & 10 & 703 & 0.2 & 0.04 & $\begin{array}{c}\text { No visible lesions were found in } \\
\text { other organs and tissues }\end{array}$ \\
2 & 10 & 1406 & 0.3 & 0.09 & $\begin{array}{c}\text { No visible lesions were found in } \\
\text { other organs and tissues }\end{array}$ \\
3 & 10 & 2812 & 0.4 & 0.16 & $\begin{array}{c}\text { No visible lesions were found in } \\
\text { other organs and tissues }\end{array}$ \\
4 & 10 & 5628 & 0.7 & 0.49 & $\begin{array}{c}\text { Lung were enlarged } \\
5\end{array}$ \\
\hline
\end{tabular}

Table 13. Effect of berberine hydrochloride on organ indexes in ICR mice by mKM

\begin{tabular}{cccccc}
\hline Dosage $(\mathbf{m g} / \mathbf{k g})$ & Hear $(\%)$ & Liver $(\%)$ & Spleen $(\%)$ & Lung (\%) & Kidney (\%) \\
\hline 0 & $0.466 \pm 0.002$ & $4.800 \pm 0.373$ & $0.387 \pm 0.079$ & $0.588 \pm 0.057$ & $1.282 \pm 0.140$ \\
703 & $0.463 \pm 0.018$ & $5.010 \pm 0.558$ & $0.406 \pm 0.092$ & $0.553 \pm 0.069$ & $1.227 \pm 0.203$ \\
1406 & $0.429 \pm 0.028$ & $4.740 \pm 0.295$ & $0.422 \pm 0.063$ & $0.645 \pm 0.097$ & $1.162 \pm 0.100$ \\
2812 & $0.454 \pm 0.017$ & $4.453 \pm 0.242$ & $0.398 \pm 0.075$ & $0.667 \pm 0.031$ & $1.198 \pm 0.131$ \\
5628 & $0.473 \pm 0.046$ & $4.575 \pm 0.173$ & $0.394 \pm 0.042$ & $0.625 \pm 0.024$ & $1.320 \pm 0.073$ \\
11250 & $0.442 \pm 0.053$ & $5.877 \pm 0.309 * *$ & $0.288 \pm 0.065^{* *}$ & $0.697 \pm 0.090^{* *}$ & $1.249 \pm 0.110$
\end{tabular}

Note: $* \mathrm{P}<0.05$ vs Normal, $* * \mathrm{P}<0.01$ vs Normal.

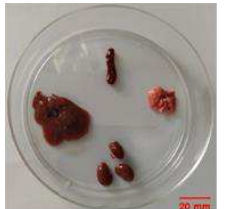

a

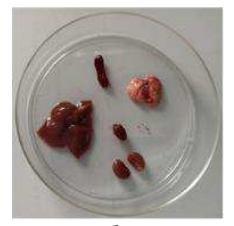

$\mathrm{d}$

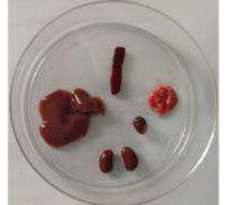

b

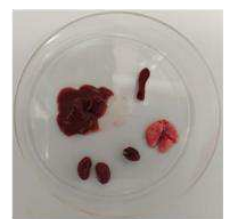

$\mathrm{e}$

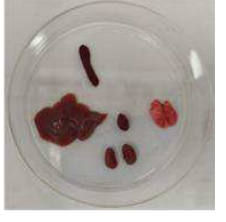

C

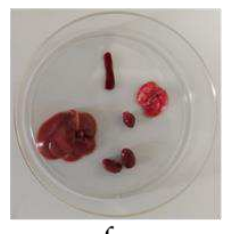

Fig. 7. Organs of mice administrated different dosage of berberine hydrochloride by mKM. (a) Control; (b) $703 \mathrm{mg} / \mathrm{kg}$; (c) $1406 \mathrm{mg} / \mathrm{kg}$; (d) $2812 \mathrm{mg} / \mathrm{kg}$; (e) $5628 \mathrm{mg} / \mathrm{kg}$; (f) 11250 $\mathrm{mg} / \mathrm{kg}$. 
In this study, nicotine, sinomenine hydrochloride and berberine hydrochloride were detected to obtained oral LD50 both by iUDP and mKM. According to toxicity categories in Classification Criteria for Acute Toxicity (Table 14) [35] and LD50 results (Table 15), the three alkaloids were divided into Category II (Highly toxic), III (Moderately toxic) and IV (Mildly toxic).

Oral LD50 is affected by many factors such as gender, age and fasting time, etc. [2]. Gender differences plays an important role in dosage-effect response [36, 37]. Females are more sensitive to compound than males [38]. It is recommended to use females for general acute toxicity studies [33]. Age, which is often poorly reported, affects the physiological state and sensitivity to substance [39]. Four to eight weeks mice $(18 \sim 30 \mathrm{~g})$ are often used in toxicity tests [40-43]. It is indicated that ICR, KM, and BALB/c mice $(26 \sim 30 \mathrm{~g})$ under the state of $8 \sim 10$ weeks are equivalent to the human adulthood [44]. To increase scientific validity and reduce experimental variability, the adult rodent animals are used in acute toxicity experiments [45]. In addition, the fasting status is often overlooked. It was reported that overnight-fasting affected the level of hormone and sensitivity of animals to drugs [46]. In this study, a 4 h-fasting is recommended for mice.

There are two reasons to choose $24 \mathrm{~h}$ as the observation interval. In the experiment, surviving mice returned to normal after $2 \sim 18$ hours administration (Table 2, 4, 6). Nicotine (highly toxic), sinomenine hydrochloride (moderately toxic) have a fast poisoning reaction which would be relieve within 4-6 hours. But unknown chemicals may take a longer time to show its toxic reaction which is the same as berberine hydrochloride ( $8-18$ hours). Second, individual differences lead to the differences between different methods [2, 47, 48]. To improve the repeatability of iUDP, the state of each animal should be as consistent as possible. It is best to fix the fasting start time and end time for each mouse. In this article, the mice were fasted daily from 9:00 am to 13:00 pm and the weight loss of each mouse was between 0.9 to $2.0 \mathrm{~g}$.

In addition, the reliability and accuracy of iUDP could be improved by choosing appropriate initial dosage and slope. Initial dosage should be valued from all known toxicity information [49]. Slope of dosage response curve is a key regulator for sequential dosage. A 
larger slope would bring a good 95\%CI, which may lead to increase animal. A smaller slope would reduce the accuracy of $95 \% \mathrm{CI}$. Once the slope setting is not suitable, the entire experiment faced the risk of failure.

Table 14. Classification Criteria for Acute Toxicity [35]

\begin{tabular}{cccccc}
\hline $\begin{array}{c}\text { Exposure } \\
\text { route }\end{array}$ & Category I & Category II & Category III & Category IV & Category V \\
& Very toxic & Highly toxic & $\begin{array}{c}\text { Moderately } \\
\text { toxic }\end{array}$ & Mildly toxic & Practically non-toxic \\
\hline $\begin{array}{c}\text { Mice, oral } \\
(\mathrm{mg} / \mathrm{kg})\end{array}$ & $<1$ & $1 \sim 50$ & $51 \sim 500$ & $501 \sim 5000$ & $5001 \sim 15000$ \\
\hline
\end{tabular}

Table 15. Comparison of acute toxicity results between iUDP and mKM in three alkaloids

\begin{tabular}{ccccccc}
\hline \multirow{2}{*}{ Method } & Compound & Category & Animals & Compound (g) & $\begin{array}{c}\text { Expense } \\
\text { (MOP) }\end{array}$ & $\begin{array}{c}\text { Duration } \\
\text { (Day) }\end{array}$ \\
\hline \multirow{2}{*}{ iUDP } & Nicotine & II & 7 & 0.0082 & 1330 & 21 \\
\cline { 2 - 6 } & $\begin{array}{c}\text { Sinomenine } \\
\text { hydrochloride }\end{array}$ & III & 7 & 0.114 & 1330 & 21 \\
\cline { 2 - 6 } & $\begin{array}{c}\text { Berberine } \\
\text { hydrochloride }\end{array}$ & IV & 9 & 1.9 & 1900 & 24 \\
\hline & Nicotine & II & 74 & 0.0673 & 14060 & 14 \\
\cline { 2 - 6 } & $\begin{array}{c}\text { Sinomenine } \\
\text { hydrochloride }\end{array}$ & III & 80 & 1.24 & 15200 & 14 \\
\cline { 2 - 6 } & $\begin{array}{c}\text { Berberine } \\
\text { hydrochloride }\end{array}$ & IV & 86 & 12.7 & 16340 & 14 \\
\hline
\end{tabular}

\section{Conclusion}

In light of experimental results, it may be concluded that iUDP is reliable to detect acute toxicity of unknown substances. And compared with traditional acute toxicity method, iUDP was more animal-friendly and economy which was suitable for valuable or minor amount substances.

\section{Supplementary Materials:}

\section{Abbreviations}


95\% CI, 95\% confidence interval; iUDP, improved up-and-down procedure; $\mathbf{L D}_{\mathbf{5 0}}$, Median lethal dosage; mKM, modified Karber method;

\section{Ethics approval and consent to participate}

The animal experiments were approved by the Division of Animal Control and Inspection, Department of Food and Animal Inspection and Control, Instituto para os Assuntos Cívicos e Municipais (IACM), Macao (AL020/DICV/SIS/2018).

\section{Consent for publication}

All authors have read and agreed the published version of the manuscript.

\section{Availability of data and materials}

All data generated or analyzed during this study are included in this published article.

\section{Competing interests}

The authors declare no conflict of interest.

\section{Funding}

This research was funded by The Science and Technology Development Fund, Macau SAR [grant number: 0027/2017/AMJ] and The National Key Research and Development Program of China [grant number: 2017YFE0119900].

\section{Author Contributions}

All the authors participated in development of the manuscript. The experiment design has mainly been developed by HZ and YYZ who also performed the statistical analyses and wrote the initial draft of the manuscript. The laboratory work was performed by YYZ, YFH and JL. All the authors have participated in the literature review and development of the manuscript and have approved the final version.

\section{Acknowledgments}

Not applicable

\section{Authors' information}

1. Faculty of Chinese Medicine and State Key Laboratory of Quality Research in Chinese Medicine, Macau University of Science and Technology, Taipa, Macao, P.R. China;

2. Zhuhai Hospital of Integrated Traditional Chinese and Western Medicine, Zhuhai City, Guangdong Province 519000, P.R. China;

3. Joint Laboratory for Translational Cancer Research of Chinese Medicine of the Ministry of Education of the People's Republic of China, Guangzhou University of Chinese Medicine, Guangzhou 510006, P.R. China 


\section{References}

332

1. Trevan, J.W., The error of determination of toxicity. 1927. 101(712): p. 483-514.

2. Zbinden, G., . and M. Flury-Roversi, . J Archives of Toxicology, Significance of the LD50-test for the toxicological evaluation of chemical substances. Arch Toxicol, 1981. 47(2): p. 77-99.

3. O'Brien, S.F. and Q.L. Yi, How do I interpret a confidence interval? Transfusion, 2016. 56(7): p. 1680-3.

4. Hespanhol, L., et al., Understanding and interpreting confidence and credible intervals around effect estimates. Braz J Phys Ther, 2019. 23(4): p. 290-301.

5. Zhang, C., et al., In vivo efficacy and toxicity studies of a novel antibacterial agent: 14-o-[(2-amino-1,3,4thiadiazol-5-yl)thioacetyl] mutilin. Molecules, 2015. 20(4): p. 5299-312.

6. Zhao, Q., et al., The Safety Evaluation of Salvianolic Acid B and Ginsenoside Rg1 Combination on Mice. International Journal of Molecular Sciences, 2015. 16(12): p. 29345-29356.

7. Zhao, Q., et al., Acute oral toxicity test and assessment of combined toxicity of cadmium and aflatoxin B1 in kunming mice. Food Chem Toxicol, 2019. 131: p. 110577.

8. Zhang, X., et al., Acute and subacute oral toxicity of polychlorinated diphenyl sulfides in mice: determining LD50 and assessing the status of hepatic oxidative stress. Environ Toxicol Chem, 2012. 31(7): p. 1485-93.

9. Saganuwan, S.A., A modified arithmetical method of Reed and Muench for determination of a relatively ideal median lethal dose (LD50). Afr. J. Pharm. Pharmacol, 2011. 5(12): p. 1543-1546.

10. Randhawa, M.A., Calculation of LD50 values from the method of Miller and Tainter, 1944. J Ayub Med Coll Abbottabad, 2009. 21(3): p. 184-5.

11. Erhirhie, E.O., C.P. Ihekwereme, and E.E. Ilodigwe, Advances in acute toxicity testing: strengths, weaknesses and regulatory acceptance. Interdisciplinary toxicology, 2018. 11(1): p. 5-12.

12. Saganuwan, S., Toxicity studies of drugs and chemicals in animals: an overview. Bulgarian Journal of Veterinary Medicine, 2017. 20(4).

13. DePass, L.R., Alternative approaches in median lethality (LD50) and acute toxicity testing. Toxicol Lett, 1989. 49(2-3): p. 159-70.

14. Müller, H. and H.-P.J.A.o.T. Kley, Retrospective study on the reliability of an "approximate LD 50" determined with a small number of animals. 1982. 51(3): p. 189-196.

15. Festing, S. and R. Wilkinson, The ethics of animal research. Talking Point on the use of animals in scientific research. EMBO reports, 2007. 8(6): p. 526-530.

16. Robinson, V., Finding alternatives: an overview of the 3Rs and the use of animals in research. School Science Review, 2005. 87(319): p. 111.

17. Russell, W.M.S. and R.L. Burch, The principles of humane experimental technique. 1959: Methuen.

18. Dixon, W.J., The Up-and-Down Method for Small Samples. Publications of the American Statistical Association, 1965. 60(312): p. 967.

19. Abd El-Aziz, T.M., et al., Comparative study of the in vivo toxicity and pathophysiology of envenomation by three medically important Egyptian snake venoms. Arch Toxicol, 2019.

20. El-Gendy, K., et al., Role of biomarkers in the evaluation of cadmium and ethoprophos combination in male mice. Environ Toxicol Pharmacol, 2019. 72: p. 103267. 
21. Aigbe, F.R., et al., Evaluation of the toxicity potential of acute and sub-acute exposure to the aqueous root extract of Aristolochia ringens Vahl. (Aristolochiaceae). J Ethnopharmacol, 2019. 244: p. 112150.

22. Abal, P., et al., Characterization of the dinophysistoxin-2 acute oral toxicity in mice to define the Toxicity Equivalency Factor. Food Chem Toxicol, 2017. 102: p. 166-175.

23. Abal, P., et al., Acute Oral Toxicity of Tetrodotoxin in Mice: Determination of Lethal Dose 50 (LD50) and No Observed Adverse Effect Level (NOAEL). Toxins (Basel), 2017. 9(3).

24. Li, Y., et al., Acute and sub-chronic oral toxicity studies of hesperidin isolated from orange peel extract in Sprague Dawley rats. Regul Toxicol Pharmacol, 2019. 105: p. 77-85.

25. Jafari, M., et al., Oral acute and sub-acute toxic effects of hydroalcoholic Terminalia chebula Retz and Achillea wilhelmsii extracts in BALB/c mice. BioMedicine, 2019. 9(4): p. 25-25.

26. Yu, Y., et al., Acute toxicity of amorphous silica nanoparticles in intravenously exposed ICR mice. PLoS One, 2013. 8(4): p. e61346.

27. Hiller, D.B., et al., Safety of high volume lipid emulsion infusion: a first approximation of LD50 in rats. Reg Anesth Pain Med, 2010. 35(2): p. 140-4.

28. Finch, S.C., M.J. Boundy, and D.T. Harwood, The Acute Toxicity of Tetrodotoxin and Tetrodotoxin-Saxitoxin Mixtures to Mice by Various Routes of Administration. Toxins, 2018. 10(11): p. 423.

29. Kheir, M.M., et al., Acute toxicity of berberine and its correlation with the blood concentration in mice. Food Chem Toxicol, 2010. 48(4): p. 1105-10.

30. Fu, S.X., et al., The toxicity and general pharnacological actions of sinomenine. Acta Pharmaceutica Sinica, 1963. 11: p. 673-676.

31. Meyer, S.A., et al., Up-and-down procedure (UDP) determinations of acute oral toxicity of nitroso degradation products of hexahydro-1,3,5-trinitro-1,3,5-triazine (RDX). Journal of applied toxicology : JAT, 2005. 25(5): p. 427-434.

32. Fan, Y., et al., Effect of extractions from Ephedra sinica Stapf on hyperlipidemia in mice. Exp Ther Med, 2015. 9(2): p. 619-625.

33. OECD, Test No. 425: Acute Oral Toxicity: Up-and-Down Procedure. 2008.

34. SUN, R.Y., A simpler and reasonably accurate method for computing the median lethal dose Acta Pharmaceutica Sinica, 1963. 10(2): p. 65-74.

35. Xu, X.Y., Discussion on the establishment of a unified "Acute Toxicity Classification Standard for Chemical Substances". Modern Preventive Medicine, 1997. 24: p. 246.

36. Gochfeld, M., Sex Differences in Human and Animal Toxicology. Toxicol Pathol, 2017. 45(1): p. $172-189$.

37. Xu, M. and F. Yang, Integrated gender-related effects of profenofos and paclobutrazol on neurotransmitters in mouse. Ecotoxicol Environ Saf, 2019. 190: p. 110085.

38. Cho, J., et al., Sex bias in experimental immune-mediated, drug-induced liver injury in BALB/c mice: suggested roles for Tregs, estrogen, and IL-6. PloS one, 2013. 8(4): p. e61186-e61186.

39. Polotsky, M., et al., Effect of age and weight on upper airway function in a mouse model. J Appl Physiol (1985), 2011. 111(3): p. 696-703.

40. Yan, S., et al., Neonicotinoid insecticides exposure cause amino acid metabolism disorders, lipid accumulation and oxidative stress in ICR mice. Chemosphere, 2019. 246: p. 125661.

41. Lee, H. and K. Park, Acute toxicity of benzalkonium chloride in Balb/c mice following intratracheal instillation and oral administration. Environ Anal Health Toxicol, 2019. 34(3): p. e2019009.

42. Xie, Y.J., et al., A new calcium(II) complex of marbofloxacin showing much lower acute toxicity with retained antibacterial activity. J Inorg Biochem, 2019. 203: p. 110905. 
43. Lee, S., et al., Acute and Subchronic Oral Toxicity of Fermented Green Tea with Aquilariae Lignum in Rodents. Evidence-based complementary and alternative medicine : eCAM, 2019. 2019: p. 8721858-8721858.

44. Dutta, S. and P. Sengupta, Men and mice: Relating their ages. Life Sciences, 2016. 152: p. 244-248.

45. Jackson, S.J., et al., Does Age Matter? The Impact of Rodent Age on Study Outcomes. Laboratory Animals, 2016. 51(2): p. 160-169.

46. Jensen, T.L., et al., Fasting of mice: a review. Lab Anim, 2013. 47(4): p. 225-40.

47. Alali, A., et al., Oral and intraperitoneal LD50 of thymoquinone, an active principle of Nigella sativa, in mice and rats. 2008. 20(2): p. 25-27.

48. Bruce, R.D., An up-and-down procedure for acute toxicity testing. Fundam Appl Toxicol, 1985. 5(1): p. 1517.

49. Spielmann, H., et al., Determination of the Starting Dose for Acute Oral Toxicity (LD50) Testing in the Up and Down Procedure (UDP) From Cytotoxicity Data. Vol. 27. 1999. 957-66. 
Figures

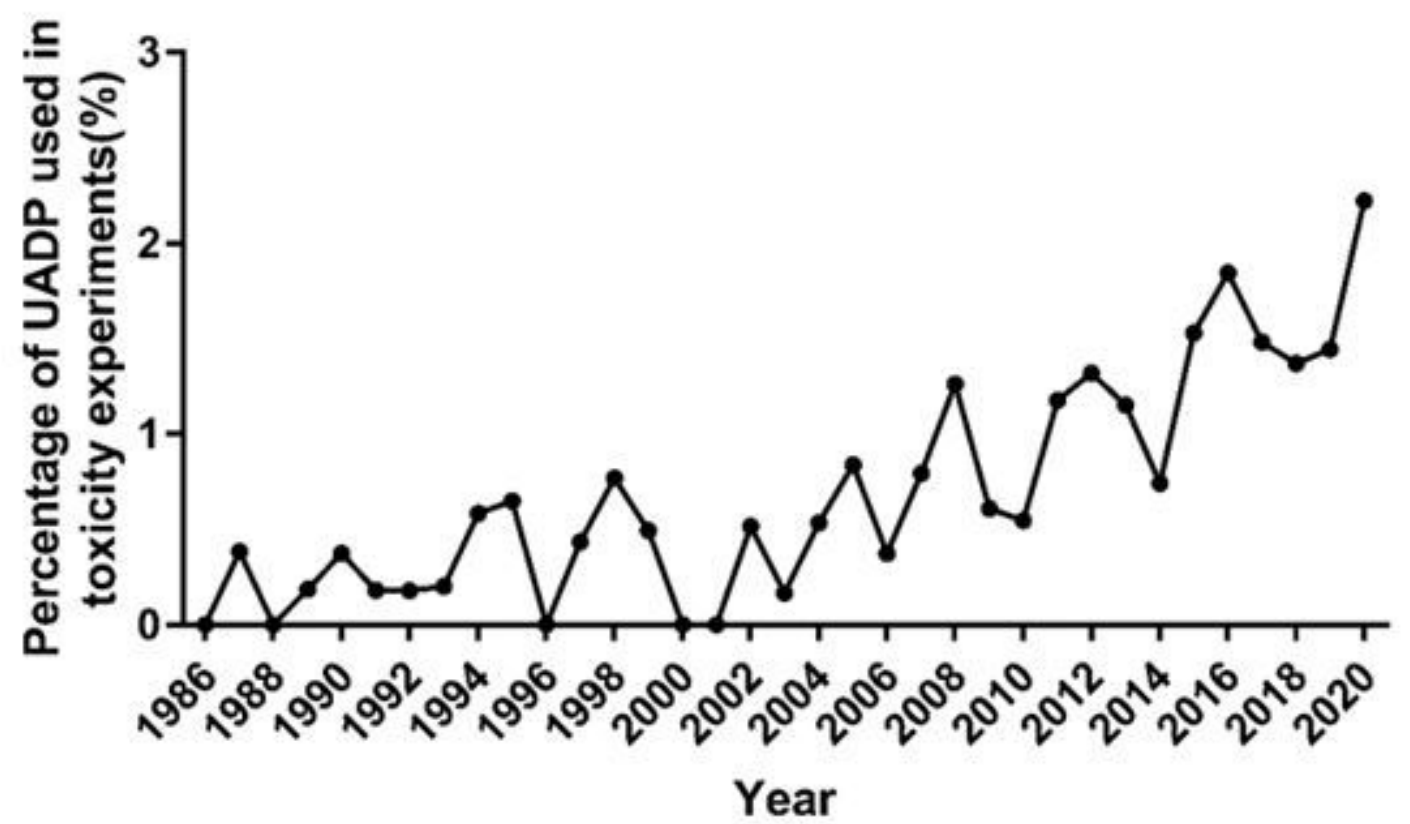

Figure 1

Percentage of UDP used in acute toxicity tests from January1986 to October 2020

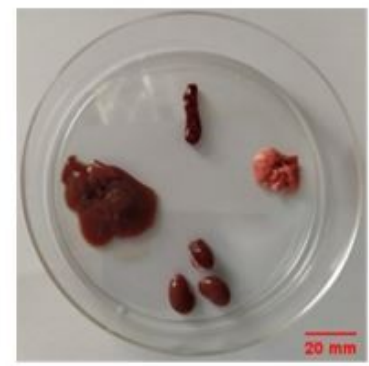

a

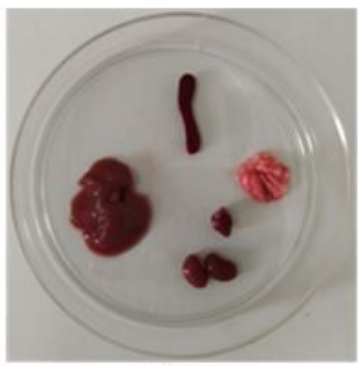

$\mathrm{b}$

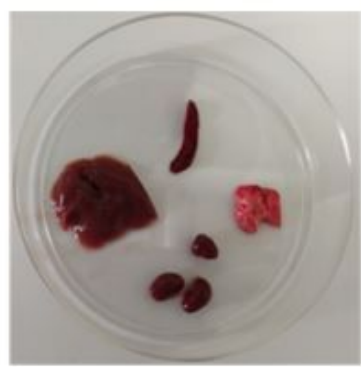

C

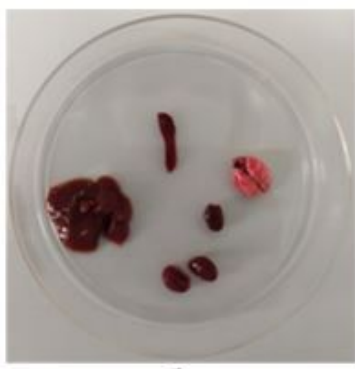

$\mathrm{d}$

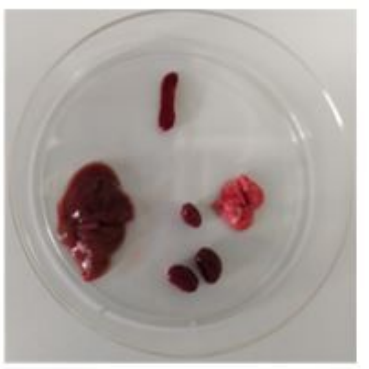

$\mathrm{e}$

Figure 2

Organs of mice administrated different dosage of nicotine by iUDP. (a) Control; (b) $12.6 \mathrm{mg} / \mathrm{kg}$; (c) 20 $\mathrm{mg} / \mathrm{kg}$; (d) $32 \mathrm{mg} / \mathrm{kg}$; (e) $50 \mathrm{mg} / \mathrm{kg}$. 


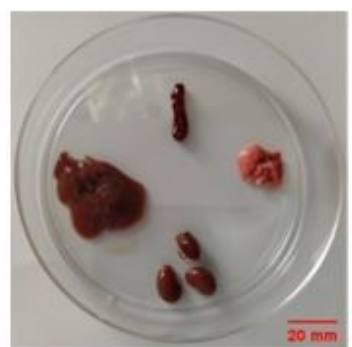

a

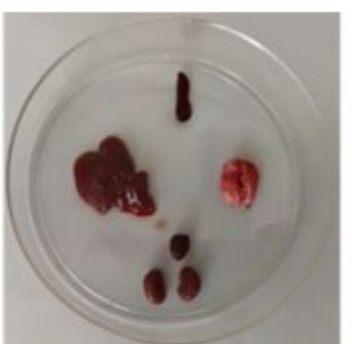

$\mathrm{b}$

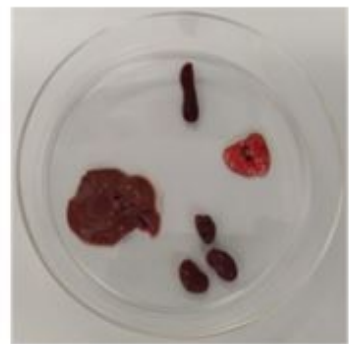

C

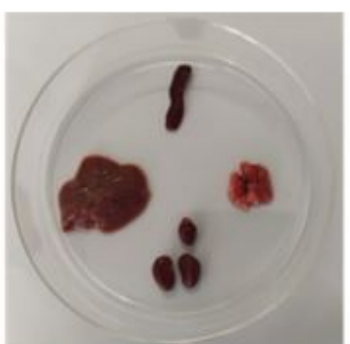

$\mathrm{d}$

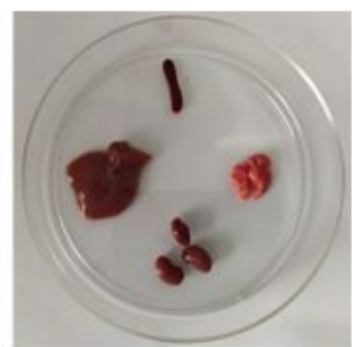

$\mathrm{e}$

\section{Figure 3}

Organs of mice administrated different dosage of sinomenine hydrochloride by iUDP. (a) Control; (b) 175 $\mathrm{mg} / \mathrm{kg}$; (c) $280 \mathrm{mg} / \mathrm{kg}$; (d) $440 \mathrm{mg} / \mathrm{kg}$; (e) $700 \mathrm{mg} / \mathrm{kg}$.

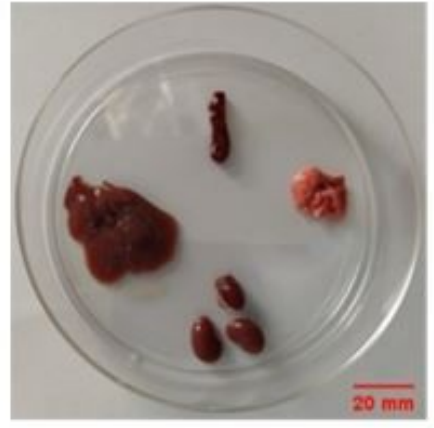

a

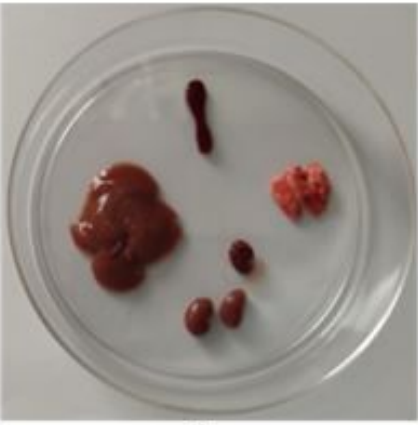

b

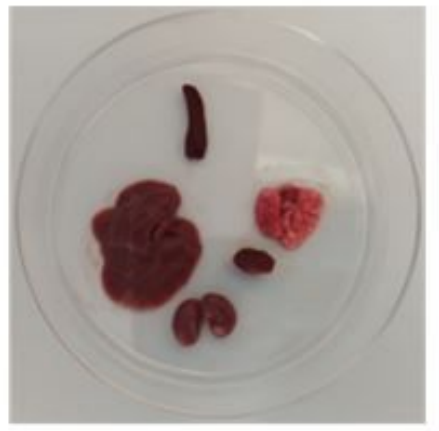

C

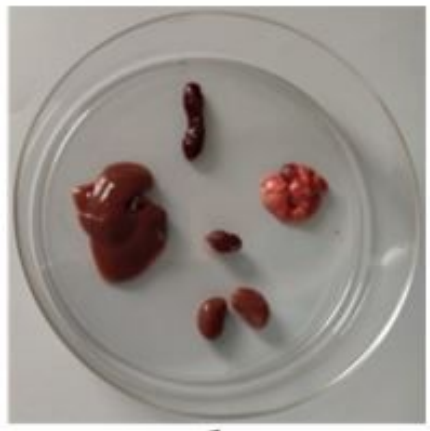

d

\section{Figure 4}

Organs of mice administrated different dosage of berberine hydrochloride by iUDP. (a) Control; (b) 790 $\mathrm{mg} / \mathrm{kg}$; (c) $2500 \mathrm{mg} / \mathrm{kg}$; (d) $5000 \mathrm{mg} / \mathrm{kg}$. 


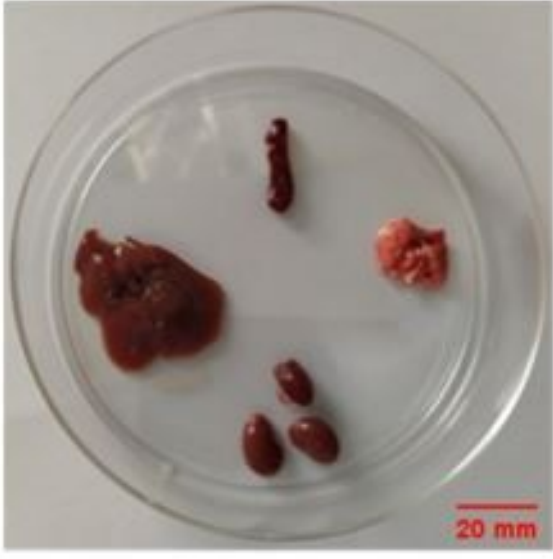

a

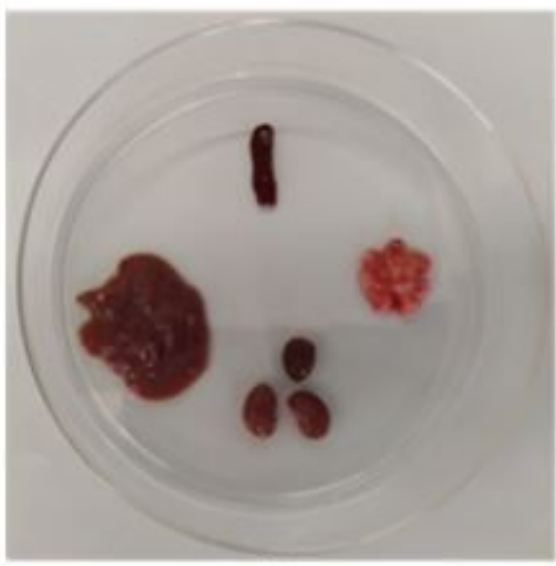

$\mathrm{d}$

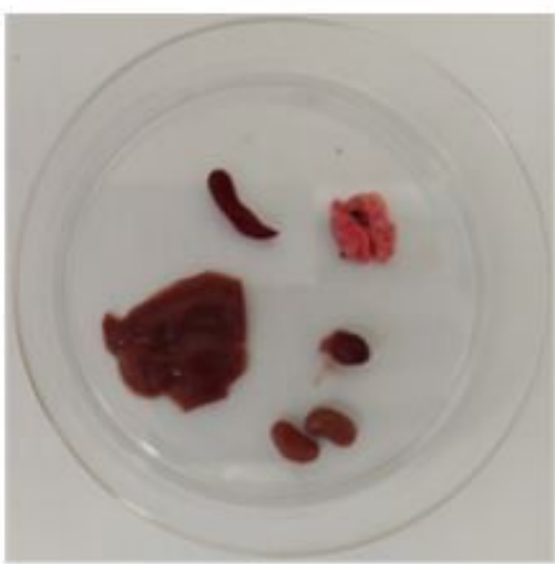

b

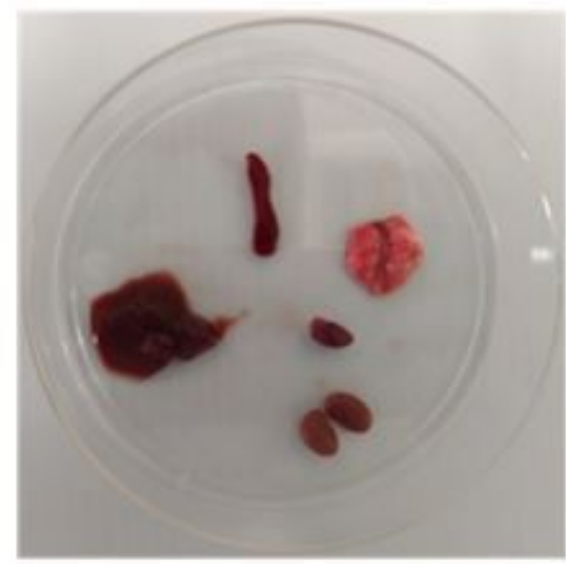

e

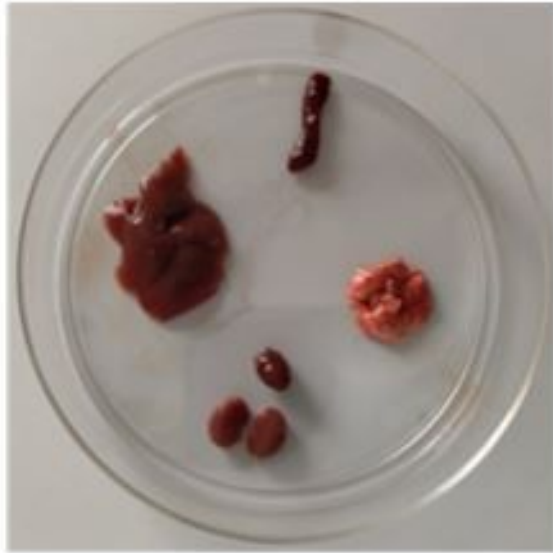

C

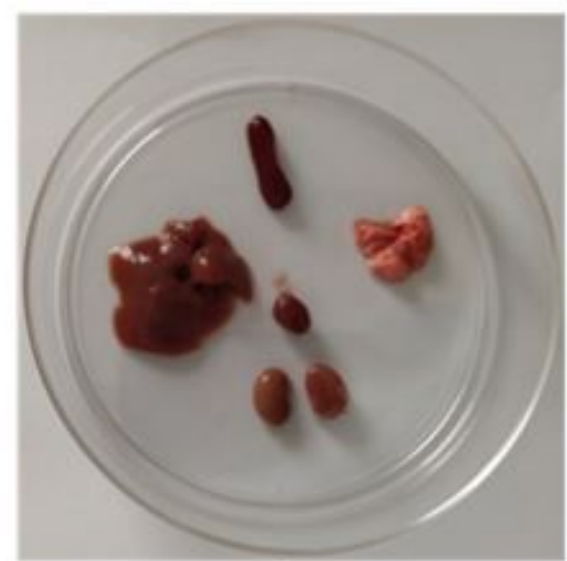

$\mathrm{f}$

Figure 5

Organs of mice administrated different dosage of nicotine by mKM. (a) Control; (b) $16 \mathrm{mg} / \mathrm{kg}$; (c) 20 $\mathrm{mg} / \mathrm{kg}$; (d) $25 \mathrm{mg} / \mathrm{kg}$; (e) $31.25 \mathrm{mg} / \mathrm{kg}$; (f) $39.1 \mathrm{mg} / \mathrm{kg}$. 


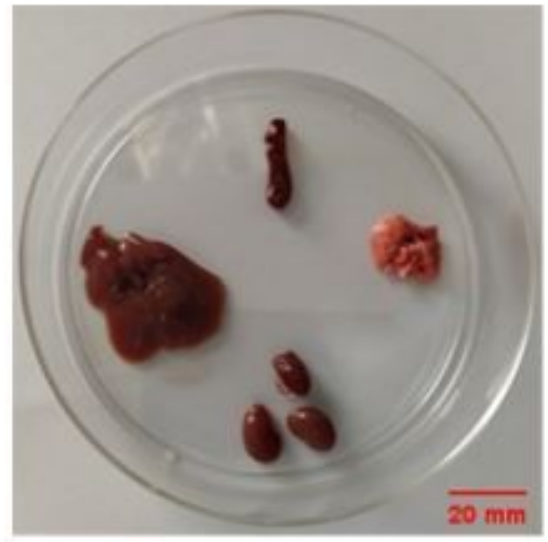

a

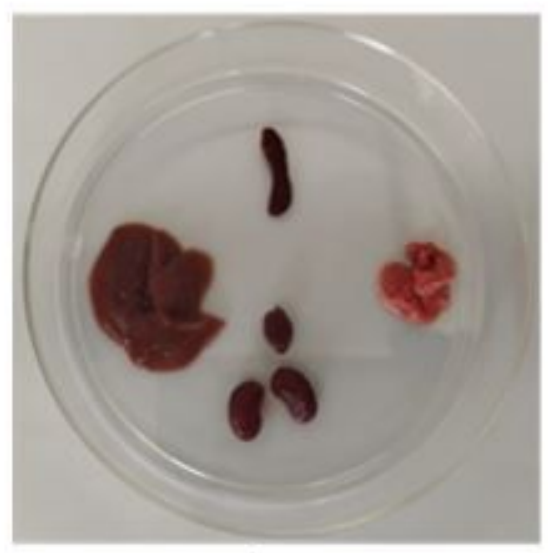

d

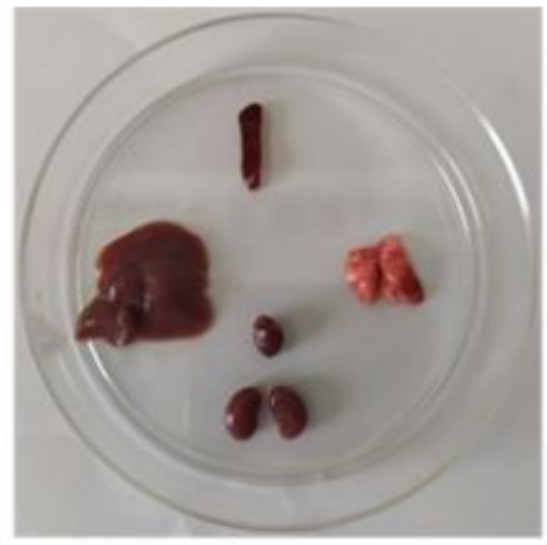

$\mathrm{b}$

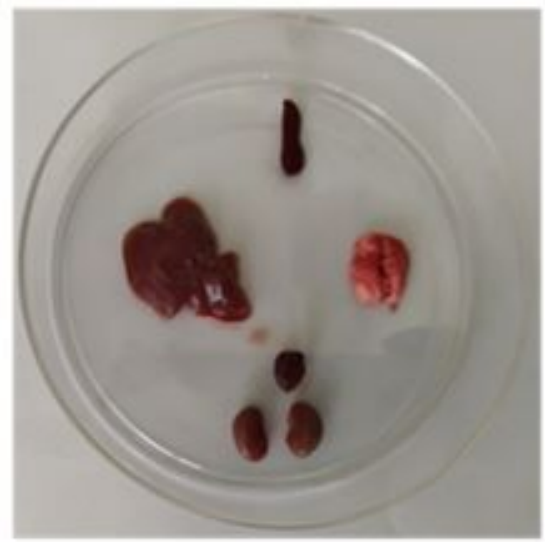

$\mathrm{e}$

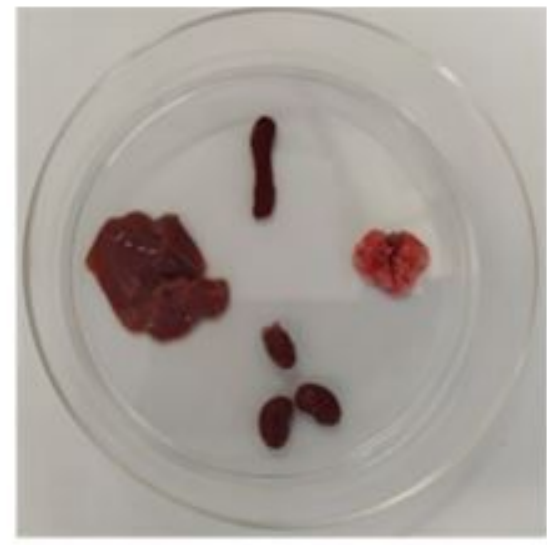

$\mathrm{C}$

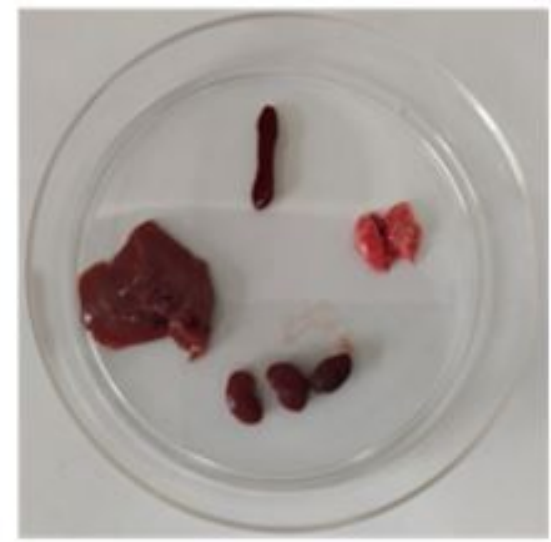

$\mathrm{f}$

Figure 6

Organs of mice administrated different dosage of sinomenine hydrochloride by mKM. (a) Control; (b) 300 $\mathrm{mg} / \mathrm{kg}$; (c) $365 \mathrm{mg} / \mathrm{kg}$; (d) $446 \mathrm{mg} / \mathrm{kg}$; (e) $544 \mathrm{mg} / \mathrm{kg}$; (f) $663 \mathrm{mg} / \mathrm{kg}$. 


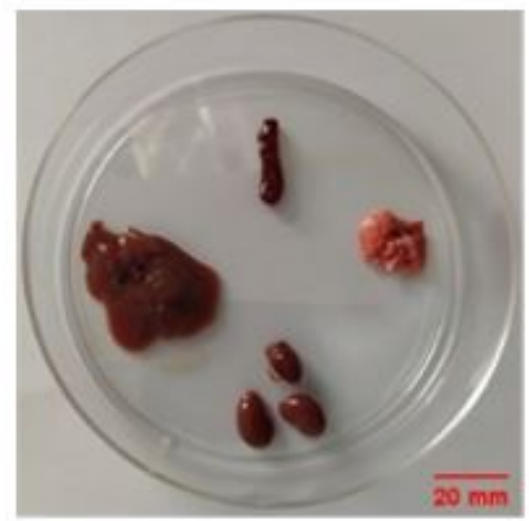

a

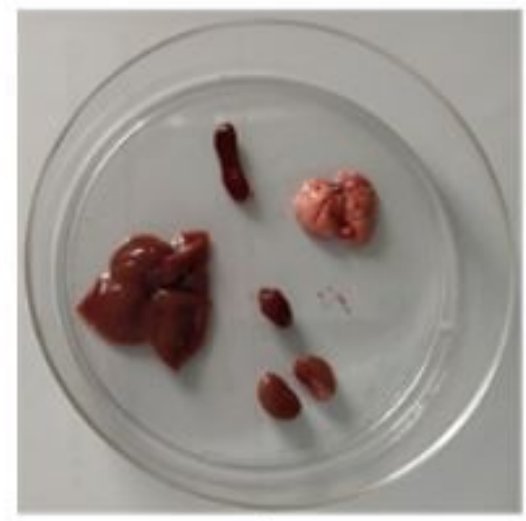

d

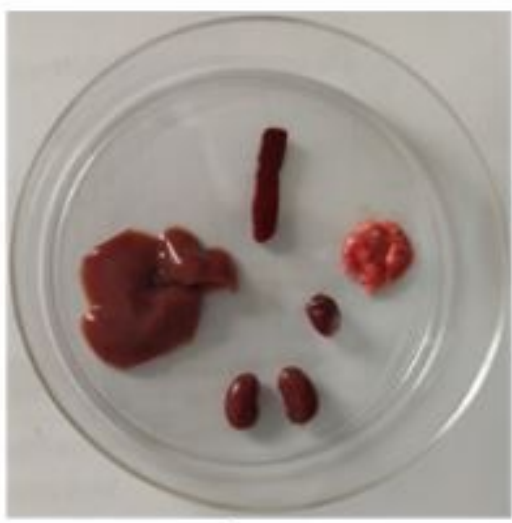

b

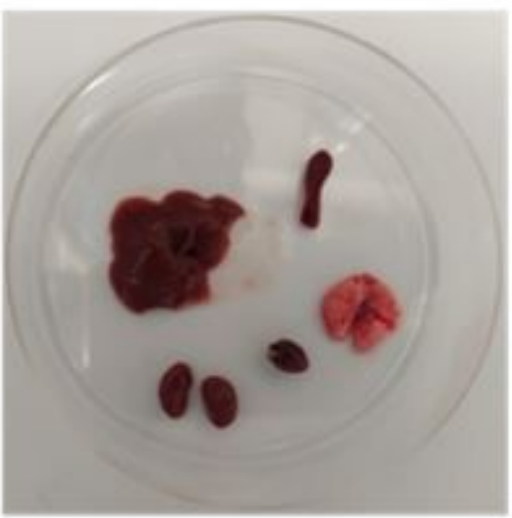

$\mathrm{e}$

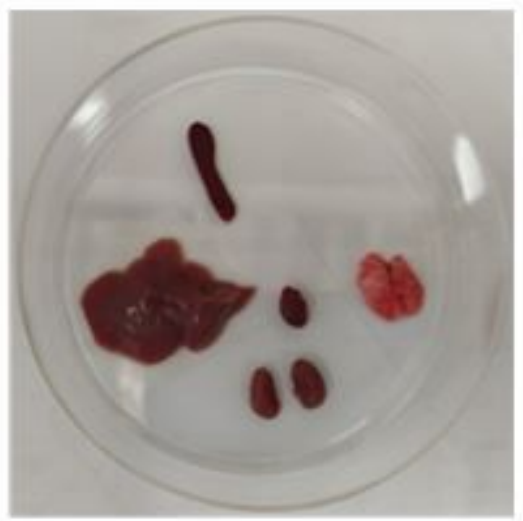

C

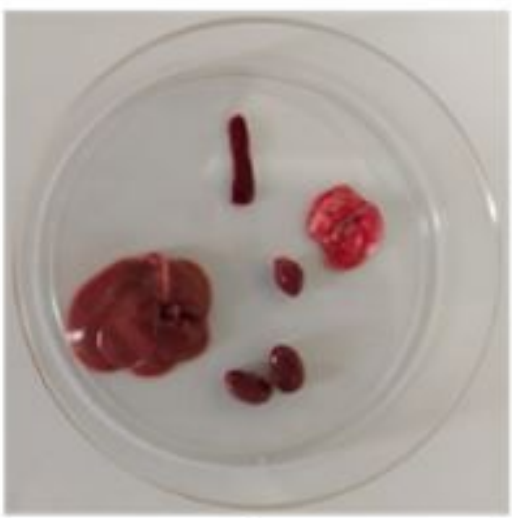

$\mathrm{f}$

\section{Figure 7}

Organs of mice administrated different dosage of berberine hydrochloride by mKM. (a) Control; (b) 703 $\mathrm{mg} / \mathrm{kg}$; (c) $1406 \mathrm{mg} / \mathrm{kg}$; (d) $2812 \mathrm{mg} / \mathrm{kg}$; (e) $5628 \mathrm{mg} / \mathrm{kg}$; (f) $11250 \mathrm{mg} / \mathrm{kg}$. 